\title{
OPTIMALISASI MEDIA SOSIAL DALAM PROMOSI OBYEK WISATA \\ DI DESA SIDOWAYAH KECAMATAN POLANHARJO \\ KABUPATEN KLATEN \\ Oleh:
}

\section{Buddy Riyanto}

Prodi Ilmu Komunikasi Universitas Slamet Riyadi Surakarta

Jl. Sumpah Pemuda No. 18 Surakarta

Email: buddy.riyanto@unisri.ac.id

\begin{abstract}
ABSTRAK
Pengabdian kepada masyarakat ini dilatarbelakangi oleh maraknya usaha wisata yang diinisiasi oleh masyarakat di berbagai wilayah Indonesia, termasuk di desa Sidowayah, kecamatan Polanharjo, Kabupaten Klaten yang memilki potensi wisata alam. Namun dalam perjalananya, upaya mempertahankan eksistensi dan pemasarannya justru menjadi beban tersendiri. Tujuan dari pengabdian ini adalah untuk mengoptimalkan penggunaan media sosial dalam promosi wisata. Metode yang digunakan adalah melaksanakan focus group discussion yang diikuti para penggiat wisata desa dan pemangku kepentingan untuk mengidentifikasi permasalahan serta menemukan alternatif solusi. Kesimpulannya adalah bahwa promosi melalui media sosial sudah dilakukan dengan baik oleh penggiat wisata, namun lebih efektif jika yang melakukan adalah para wisatawan yang puas menyebarluaskan pengalaman mereka dalam wisata di desa Sidowayah.
\end{abstract}

Kata kunci: media sosial, promosi wisata, Sidowayah

\section{A. Pendahuluan}

Letak wilayah desa Sidowayah kecamatan Polanharjo kabupaten Klaten berada di pinggir utara dari wilayah kabupaten Klaten berbatasan langsung dengan wilayah kabupaten Boyolali. Secara geografis desa tersebut terletak pada $6^{\circ} 51^{\prime} 46^{\prime \prime}-7^{0} 11^{\prime} 47^{\prime \prime}$ LS dan $109^{\circ} 40^{\prime} 19^{\prime \prime}-110^{\circ} 03^{\prime} 06^{\prime \prime} \mathrm{BT}$. Selain memiliki potensi wisata, desa tersebut juga merupakan desa yang memilik lahan tanah sangat subur, tercatat saat ini Desa Sidowayah memiliki luas lahan pertanian kurang lebih 92 Ha.

Desa yang berdiri pada tahun 1912 ini merupakan desa paling utara di Kabupaten Klaten, mempunyai lingkungan alam yang sejuk nan alami, jauh berbeda dari kedaan perkotaan saat ini. Dengan keadaan tersebut Pemerintah Desa Sidowayah membangun beberapa obyek wisata unggulan yang berkonsep nuansa alami pedesan. 
Desa ini memiliki visi “Terwujudnya masyarakat Sidowayah yang maju, sejahtera dan desa bebas kumuh menuju desa wisata tahun 2020”. Dengan misi Meningkatkatkan kesadaran masyarakat tentang pentingnya lingkungan yang bersih dan sehat, serta meningkatkan sumber daya alam dan manusia guna menuju Sidowayah sebagai Desa Wisata. Mengembangkan wisata alam dan Tradisioal. Ikon Umbul Kemanten dengan nuansa yang benar-benar alami dipertahankan keasliannya, bahkan akan dipadu dengan wisata terpadu yang akan memanjakan wisatawan yang datang berkunjung.

Program dari Pemerintah Desa Sidowayah bersama BUMDes SINERGI, dapat berhasil selain karena kuatnya kerja bersama komponen yang ada, juga banyak mendapat dukungan masyarakat. Hal ini terbukti belum lama ini warga desa Sidowayah, mendirikan wahana wisata edukasi bagi anak- anak secara swadaya, bernama Omah Aneka Satwa dan Seni (OASSE).

Permasalahannya adalah bahwa desa Sidowayah bukanlah satu-satunya daerah yang mengembangkan potensi alam sebagai obyek wisata. Kini banyak wilayah di Jateng, Jatim, Jabar, dan DIY yang kreatif mengembangkan kekayaan dan keunikan alam sebagai potensi kujungan wisatawan dan berhasil menyedot wisatawan domestik dari berbagai wilayah sehingga secara langsung dan tidak langsung dapat meningkatkan kesejahteraan ekonomi masyarakatnya.

Sejalan dengan maraknya penggunaan smartphone, ternyata mengubah gaya hidup masyarakat. Perilaku manusia berubah. Kini cenderung berinteraksi dengan sesama melalui media sosial. Melalui media sosial saling menginformasikan hal-hal baru, tempat wisata yang Instagramable, serta variasi kuliner unik. Dengan realitas tersebut maka promosi wisata juga memanfaatkan kehandalan media sosial.

Demikian pula yang telah dilakukan penggiat wisata di desa Sidowayah, berpromosi dengan memanfaatkan semua media sosial yang ada. Namun peningkatan jumlah kunjungan wisatawan belum sesuai harapan, bahkan tidak stabil, naik - turun. Pemanfaatan media sosial untuk promosi wisata alam pedesaan perlu trik dan kreativitas.

\section{B. Metode Pelaksanaan}

Kegiatan pengabdian kepada masyarakat ini direncanakan dilakukan dengan metode sebagai berikut:

1. Melakukan kontak dengan penggiat wisata di desa Sidowayah kecamatan Polanharjo kabupaten Klaten

2. Melakukan survey, serta mengidentifikasi masalah dan peluang 
3. Melakukan pertemuan dengan warga untuk menyampaikan gagasan tentang pengembangan promosi wisata di desa Sidowayah.

4. Melaksanakan focus group discusion dengan penggiat wisata untuk memastikan permasalahan yang dapat ditangani melalui kegiatan ini.

5. Melaksanakan focus group discusion dengan para pemangku kepentingan desa wisata Sidowayah untuk mengetahui keterlibatan mereka secara riil dalam penyusunan dan penerapan kebijakan, pelaksanaan program dan potensi pendanaan.

6. Dalam setiap proses pertemuan dan diskusi, permasalahan dan masukan pemikiran dicatat dan kemudian dianalisis bersama-sama secara integratif. Hasil akhirnya berupa kesimpulan sebagai masukan bagi strategi promosi wisata desa Sidowayah.

Dari tahapan perencanaan tersebut, semula direncanakan ada kegiatan pelatihan penggunaan media sosial untuk promosi wisata, tetapi tidak jadi dilakukan karena kenyataan di lapangan berbeda dengan asumsi awal, yaitu bahwa kami datang untuk memberi pelatihan pemanfaatan media sosial untuk promosi desa wisata, pada kenyataannya mereka sudah cukup mahir melakukannya.

\section{Hasil dan Pembahasan}

Berikut tentang hasil dan pembahasan disajikan sesuai dengan tahapan-tahapan utama dalam kegiatan pengabdian kepada masyarakat kali ini, yaitu Penyampaian gagasan dalam Pertemuan Warga Desa Sidowayah, Diskusi Dengan Para Penggiat Desa Wisata, dan Diskusi Dengan Para Pemangku Kepentingan.

\section{C.1. Potensi Wisata Alam Desa Sidowayah}

Penyampaian gagasan tentang pengembangan promosi wisata desa Sidowayah disampaikan dalam pertemuan Warga desa Sidowayah yang diselenggarakan pada hari sabtu tanggal 1 September 2018 di Balai Desa Sidowayah.

Pertemuan yang dihadiri oleh 36 0rang warga, sebagian besar Bapak-Bapak ini, terdiri dari Bapak Kepala Desa Sidowayah, Aparat Desa, Penggerak PKK, Pengurus RT/RW serta para Penggiat Wisata Desa Sidowayah. Pertemuan berlangsung mulai pukul 09.00 hingga 11.30 sebelum azan dhuhur, diisi dengan sambutan Kepala Desa, pemaparan materi tentang “Optimalisasi Media Sosial 
Dalam Promosi Obyek Wisata di Desa Sidowayah” dilanjutkan tanya jawab. Forum ini sekaligus untuk menggali keunggulan obyek wisata serta permasalahanpermasalahan yang ada.

Dari forum ini diketahui bahwa penggunaan berbagai media sosial sudah dilakukan oleh para penggiat desa wisata. Mereka sudah mahir dalam memanfaatkan media sosial tersebut, antara lain facebook, Instagram, dan Whatsapp. Namun demikian kehadiran Tim Unisri tetap diharapkan dapat memberi kiat-kiat untuk meningkatkan jumlah wisatawan, terutama kalangan remaja \& dewasa umum, karena selama ini yang banyak datang dari kalangan anak-anak TK, SD \& SMP serta oarang tua/dewasa seringnya kelompok Ibu-Ibu.

\section{C.2. Pengembangan Obyek Wisata Alam Dan Tradisional Desa Sidowayah}

Wisata di Sidowayah lebih mengunggulkan pada wisata alam dan suasana tradisioal. Ikon Umbul Kemanten dengan nuansa yang benar-benar alami akan tetap dipertahankan keasliannya, bahkan kini telah dilengkapi dengan wisata terpadu yang diharap dapat memanjakan wisatawan yang datang berkunjung.

Dalam diskusi dengan para penggiat wisata desa Sidowayah pada hari Sabtu tanggal 6 Oktober 2018 diketahui bahwa penataan kawasan wisata terpadu yang mulai dirintis tahun 2016 meliputi:

1. Pusat Pemerintahan dan Pendidikan, menjadi pusat perkantoran antara lain kantor desa, kantor BUMDes, kantor LKM, Polindes dan Pendidikan SD/MIN, Paud, TPA, Rumah Tahfidz dan SMP.

2. Kawasan Wisata Terpadu antara untuk memanjakan wisatawan yang bekunjung ke Sidowayah maka mulai dibangun pengembangan wisata Umbul Kemanten, Wisata Kebun Markisa, Home Stay, Wisata Danau Buatan, Outbond Remaja, Fun Rubing, Susur Sungai, Kampong Dolanan dan Joglo Edukasi Pertanian.

3. Kawasan Agro Komplek, dibidang pertanian Sidowayah juga sudah lama berbenah untuk meningkatkan uasha pertanian dan perikanan antara lainPertanian Organik baik secara tradisional maupun moderen juga telah dibangun rumah kompos. Selain itu juga dikembangkan peternakan sapi, kambing, kelinci, itik, ayam serta perikanan dan pembenihan ikan nila, lele dan budidaya lumut. 
4. Kawasan Perdagangan dan Jasa, untuk lebih meningkatkan ekononi masyarakat akan dibangun outlet UKM, wisata kuliner ikan, pasar burung, pasar hewan, pasar desa dan klitikan.

5. Industri Kreatif antara pengembangan usaha selimut, handuk, block board, dolanan anak, rumah kemasan, kue semprong, kripik jamur, emping, opor bebek dan nila bakar maupun goreng.

6. Kawasan Penyangga Konservasi Area, antara lain dikembangkannya budidaya kebun buah, kebun bunga, kebun efogia, green garden RT, Pertanian Organik, apotik hidup, lapangan olah raga, wisata religi.

7. Kawasan Komersil, untuk kawasan ini juga sudah mulai diupayakan yaitu pembangunan pertokoan dan perumahan.

Dengan konsep kembali ke alam dan tradisional pengembangan wisata Sidowayah lebih mengoptimalkan tradisi leluhur desa Sidowayah, agar nantinya anak-anak kita yagng lahir di era moderen ini tidak lupa dengan peninggalan orang tua kita. Untuk itu pengembangan Umbul Kemanten yang menjadi iko desa Sidowayah tetap dipertahankan keaslianya.

Sedang Kampong Dolanan yang sudah mulai dibuka untuk paket kunjungan wisata beberapa tahun yang lalu, wahana ini bermula dari rasa keprihatinan Pemdes Sidowayah yang mengingat bahwa saat ini banyak anak-anak yang lebih cenderung aktif bermain mainan modern seperti playstation, gadget, dan game online. Maka dari itu dibangunlah Kampong Dolanan, pengunjung bisa melihat ataupun bermain mainan tradisional seperti baksodor, obrok, jamuran, nekeran dan masih banyak lagi.

Pengembangan Bukit Sibalarak juga menjadi prioritas dari Pemdes Sidowaya dan BUMDes Sinergi, yaitu akan dijadikan kawasan wisata yang indah dan menyejukkan, antara lain Siblarak Waterpark, sawah lestari, camping area, oudbond area, taman bermain, arena kuliner, Resort Siblarak, Area Waterstacked/air bersusun, air terjun tirai kelambu.

Di Sidowayah yang daerahnya kaya akan keindahan alam yang sejuk, umbul yang masih asri, hamparan sawah yang dikelola dengan tradisional dan moderen serta aliran sungai-sungai kecil dengan air yang jernih, dapat dinikmati oleh wisatawan dengan keliling di area Sidowayah dengan naik kuda atau sepeda ontel.

Bahkan wisatawan dengan memakai baju petani bisa ikut terjun kesawah membaur dengan petani ikut bercocok tanam atau naik bajak sawah yang 
dikendalikan oleh binatang kerbau dan bersantai di Home Stay sambil menikmati menu makan khas desa dengan pincuk dari daun pisang.

\section{C.3. Peran Serta Masyarakat Dalam Program Wisata Desa Sidowayah}

Diskusi dengan para pemangku kepentingan diselenggarakan pada hari Sabtu tanggal 3 November 2018. Maksud dari diskusi ini adalah untuk memperoleh gambaran tentang usaha pemerintah desa dalam menggerakan peran serta masyarakat dan kemungkinan apalagi yang dapat diOptimalkan. Hasilnya sebagai berkut:

Desa Sidowayah berdiri pada tahun 1912, pada waktu itu desa tersebut bernama Kelurahan Nglungge dengan lurahnya bernama R. Ng. Purbontani. Namun karena pada tahun 1934 kelurahan itu terjadi banyak kerusuhan dan banyak yang terbakar, kemudian Kelurahan Nglungge di ganti nama menjadi Sidowayah. Nama Sidowayah sendiri diambil dari sebuah nama makam yang berada di desa tersebut.

Kepala Desa Sidowayah, Hapsoro SH. mengatakan, desa ini merupakan desa paling utara di Kabupaten Klate, mempunyai lingkungan alam yang sangat sejuk nan alami, jauh berbeda dari kedaan perkotaan saat ini. Dengan keadaan tersebut Pemerintah Desa (Pemdes) Sidowayah akan siapkan beberapa wisata unggulan yang berkonsep nuansa alami dan pedesan.

"Dengan visi dan misi terwujudnya masyarakat Sidowayah yang maju, sejahtera dan desa bebas kumuh menuju desa wisata tahun 2020. Meningkatkatkan kesadaran masyarakat tentang pentingnya lingkungan yang bersih dan sehat, serta meningkatkan sumber daya alam dan manusia guna menuju Sidowayah sebagai Desa Wisata,” ungkapnya.

Program dari Pemerintah Desa Sidowayah bersama BUMDes SINERGI, dapat berhasil selain karena kuatnya kerja bersama komponen yang ada, juga banyak mendapat dukungan masyarakat. Hal ini terbukti belum lama ini warga desa Sidowayah, mendirikan wahana wisata edukasi bagi anak- anak secara swadaya. Wahana bernama Omah Aneka Satwa dan Seni (OASSE) tersebut diresmikan oleh Bupati Klaten, Sri Mulyani. "Ini salah satu unit usaha pariwisata terbaru di BUMDes Sinergi Sidowayah. Karena sebelumnya sudah ada wisata air Umbul Temanten, dan Kampung Dolanan Sidowayah (KDS),” kata Hapsoro. 
Berbeda dengan dua unit usaha pariwisata sebelumnya, kata dia, wahana OASSE merupakan pilot project kolaborasi masyarakat. Sebab sebanyak 45 KK di RT 10/RW 05 Dukuh Kayuhan berinisitif merogoh koceknya masing- masing Rp 500 ribu. Sedangkan ujung tombak pemasaran ialah BUMDes Sinergi.

OASSE ini murni dibiayai swadaya masyarakat satu RT. Dengan memanfaatkan rumah kosong, tiap KK berani iuran Rp 500 ribu. Harapannya, kolaborasi kesadaran sendiri untuk berinvestasi ini bisa menular ke 16 RT lainya. Sehingga semakin memperkuat keberadaan desa wisata Sidowayah. Jadi begitu selesai outbound di KDS, anak- anak datang ke sini diantar naik bendi. Adapun fasilitasnya berupa panahan, seni lukis, membuat gerabah, hingga kebun binatang mini berisi aneka unggas, burung, kura- kura, kambing, hingga kuda. Biayanya di OASSE sementara ini cukup Rp 10 ribu, kalau paket lengkap termasuk makan siang dan snack 65 ribu per anak,

\section{C.4. Mengoptimalkan Media Sosial Untuk Promosi Obyek Wisata Desa Sidowayah}

Jumlah pengguna media sosial di Indonesia saat ini sudah sangat besar, hal itu tidak terlepas penetrasi internet di Indonesia yang telah mencapai 132,7 juta dari total penduduk Indonesia tahun 2016. Persentase penetrasi internet di Indonesia per wilayah. Fakta ini membuka peluang besarnya peluang melakukan promosi pariwisata melalu sosial media.

Saat ini sepuluh (10) jenis sosial media dengan pengguna aktif terbanyak di Dunia adalah: Facebook, WhatsApp, Youtube, Facebook Messenger, WeChat, QQ, Instagram, Qzone, Tumblr, dan Twitter. Dua jenis sosial media dengan tingkat penggunaan tertinggi di Indonesia adalah Twitter dan Facebook. Per Mei 2016, Indonesia menduduki peringkat ke-3 sejagat atau 24 juta pengguna aktif Twitter. Sedangkan untuk Facebook, Indonesia menduduki peringkat ke-4 sejagat dengan jumlah pengguna aktif sebesar 126 juta per Juli 2017.

https://www.statista.com/statistics/268136/top-15-countries-based-on-number-offacebook-users/.

Penggunaan media sosial diberbagai kegiatan telah terbukti memiliki daya pengaruh yang sangat ampuh, tergantung dari penggunanya untuk keperluan apa ?. Media baru ini telah terbukti efektif menyebarluaskan inovasi kesehatan di Korea Selatan (Shim, 2014), menggerakkan revolusi Arab Spring di kawasan Timur 
Tengah ( Obeid, 2015), bahkan mempromosikan terorisme global, sebagai saluran propaganda ISIS (Riyanto, 2016).

Potensi inilah yang dilihat Kementerian Pariwisata Indonesia menggunakan media sosial untuk mempromosikan pariwisata Indonesia. Fakta lainnya bahwa perilaku konsumen Indonesia juga telah berubah, dari gaya hidup konvensional menjadi gaya hidup digital (digital lifestyle) yang berciri: mobile, personal dan interactive.

Menurut Kemenpar, 70 \% konsumen pariwista Indonesia melakukan search and share melalui media digital dan media digital 4 kali lebih efektif dibandingkan media konvensional. Fakta lain adalah, perilaku konsumen Indonesia telah berubah dalam hal mencari, memesan dan membayar (Looking, Booking, Paying).

Looking: perubahan perilaku konsumen Indonesia yang melakukanpencarian informasi pariwisata melalui: Google, Baidu, dan Tripadvisor. Booking: perubahan perilaku konsumen Indonesia yang melakukan pemesaan melalui Traveloka, Booking.com, AliTrip atau C-Trip dimana tersedia juga aplikasinya. Dan Paying, yaitu perilaku konsumen Indonesia yang melakukan pembayaran online/transaksi online melalui: ATM, Amazon, Paypal, Alipay, GoPay, dll (Siagian, 2018).

Dari data tersebut nampak peluang untuk mempromosikan potensi yang dimiliki desa melalui media sosial sangatlah besar. Potensi desa bisa saja didokumentasikan kemudian di-posting melalui media sosial. Bahkan bisa didokumentasikan dalam rangka menceritakan kepada masyarakat luas.dengan begitu para pengguna media sosial nusantara bahkan mancanegara akan tertarik dan datang untuk menikmati ojek wisata, kearifan lokal adat istiadat, budaya dan produk yang ada di desa. Namun, yang perlu dipersiapkan juga adalah sumber daya manusia (SDM) dalam mengelola promosi melalui media sosial tersebut (Rustam, 2017).

Di desa Sidowayah, semua obyek wisata beserta aktivitas wisatawannya oleh para penggiat wisata desa telah dipromosikan melalui media sosial dan sudah viral secara luas. Namun akhirnya kami menyimpulkan bahwa komunikasi secara gethok tular, secara face to face atau melalui media sosial, yang dilakukan sendiri oleh wisatawan secara suka rela lebih efektif karena tidak terkesan promosi tetapi merupakan “kesaksian” langsung dari wisatawan sebagai "konsumen”, dan muaranya adalah teman-teman serta saudara mereka yang kemudian datang berbondong-bondong berwisata ke desa Sidowayah.. Para wisatawan yang datang 
berasal tidak sekedar dari wilayah Klaten, tetapi dari Solo Raya, DIY, Salatiga, Semarang, Puwokerto, Tegal, bahkan pernah ada juga yang dari Jawa Timur, Jawa Barat dan DKI.

Dari kesimpulan di atas dapat disarankan bahwa untuk meningkatkan jumlah wisatawan perlu penambahan obyek wisata yang ditonjolkan khusus kalangan remaja. Kemudian berbagai obyek, permainan, dan pelayanan dioptimalkan agar dapat menimbulkan kesan baik yang mendalam sehingga akan meperderas arus komunikasi gethok tular melalui media sosial yang dilakukan secara sukarela oleh para wisatawan. 


\section{Daftar Pustaka}

Obeid, Azam A.,2015, Social Media Impact on Arab Spring, a Comparasion Study between Four Middle Eastern Countries, ProQuest number: 1606040, Published by ProQuest LLC (2015) http://search.proquest.com/docview/1755941431

Riyanto, Buddy, 2016, Propaganda NIIS Melalui Media Sosial dan Persepsi Mahasiswa Islam Surakarta, Jurnal Ilmu Sosial Dan Humaniora: Eksplorasi (ISSN 0853-7054) Vol XXVIII No.2 Feb 2016, hal 223-235

Rustam, Qudratullah, 2017, Promosi Potensi Desa Melalui Media Sosial, http://makassar.tribunnews.com/2017/10/10/promosi-potensi-desa-melalui-mediasosial.

Siagian, Marahalim, 2018, Media Sosial Sebagai Sarana Promosi Pariwisata, https://www.academia.edu/35713542/Media_Sosial_Sebagai_Sarana_Promosi_Pariwi $\underline{\text { sata }}$

Shim, Kyujin, 2014, Impact of Social Media on Power Relations of Korean Health Activism, Media and Communication (ISSN: 2183-2439) Vol.2 Isue 2, p72-83 - ProQuest http://search.proquest.com/docview/1628558910/fulltextPDF/30ECF8FCCDB74DC3 $\underline{\mathrm{PQ} / 4 \text { ?accountid }=62691}$

NN, https://www.statista.com/statistics/268136/top-15-countries-based-on-number-offacebook-users/. 